\title{
THE EFFECT OF THE PERCEPTION OF ELECTRONIC MONEY ON CONSUMPTIVE BEHAVIOR OF STEI SEBI STUDENTS
}

\author{
Nailah Fauziah ${ }^{1}$, Nining Nurhasanah ${ }^{2}$
}

${ }^{I}$ SEBI: Email: nailahfauziahs@gmail.com ${ }^{2}$ SEBI Lecturer Email; nining2010@ gmail.com

\begin{abstract}
In the era of industrial revolution 4.0, technological developments made changes in the lifestyle of the modern generation. The purpose of this study was to analyze the perception of the use of electronic money, whether it supports the consumptive research of STEI SEBI students. The electronic money acceptance model in this study uses the Technology Acceptance Model (TAM), and the indicators used to measure the consumptive level of STEI SEBI students are indicators of consumptive behavior. The research used is descriptive-quantitative. The data used are primary data sent from questionnaires distributed to STEI SEBI students. The method of analysis in this study uses a simple regression analysis. The results of this study indicate that electronic money has a positive and significant influence on the consumptive students of STEI SEBI, users using high electronic money than making consumptive STEI SEBI students will also increase.
\end{abstract}

Keywords: Technology Acceptance Model; Electronic Money; Consumptive Behavior

\section{INTRODUCTION}

Innovations in electronic payment instruments using cards have developed into more practical forms. At present, electronic money in Indonesia is becoming more and more popular (Indonesia, n.d.). The development of information technology has changed people's daily lives. In the past, people had to carry cash, now they only need to have a chip or server with them. It makes human activities more efficient and practical. The presence of electronic money unwittingly creates an entirely new market at a much lower price and more practical use.

Table 1.1 the circulation of Electronic Money

\begin{tabular}{|c|c|}
\hline Period & Total amount \\
\hline 2013 & $36,225,373$ \\
\hline 2014 & $35,738,233$ \\
\hline
\end{tabular}


64 |Nailah Fauziah, Nining Nurhasanah : The Effect of The Perception of Electronic Money on Consumptive Behavior of STEI SEBI Students

\begin{tabular}{|c|c|}
\hline 2015 & $34,314,795$ \\
\hline 2016 & $51,204,580$ \\
\hline 2017 & $90,003,848$ \\
\hline 2018 & $167,205,578$ \\
\hline 2019 & $292,299,320$ \\
\hline $\begin{array}{c}2020 \\
\text { (January) }\end{array}$ & $313,785,298$ \\
\hline
\end{tabular}

Source: Bank Indonesia, 2020

The amount of electronic money is the amount of electronic money in circulation in the community in a certain period. Based on Bank Indonesia (BI) data, as of January 2020, the amount of electronic money in circulation was $313,785,298$, or it increased to $7.35 \%$ compared to 2019 .

\section{Diagram 1.1 Volume and Value of Electronic Money Transactions}

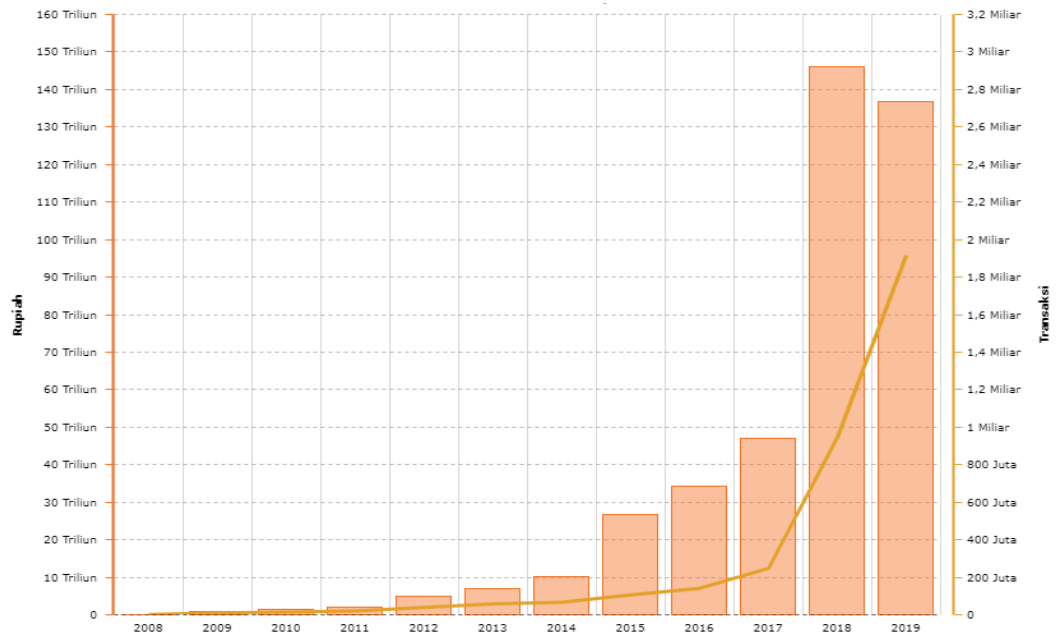

Source: Bank Indonesia, 2019

In addition to the increased amount of electronic money in circulation, the amount of electronic money in transactions has also climbed up quite dramatically. According to the data of Bank Indonesia (BI), the transactions at the end of 2018 jumped $209.8 \%$ to 2.9 billion transactions compared to 2017 
which was 943.3 million transactions. Until July 2019, the electronic money transactions has reached 2.7 billion transactions. The value of electronic money transactions also increased dramatically to $281.39 \%$. In 2018, it reached Rp 47.2 trillion. This figure increased by Rp. 34.8 trillion or almost tripled compared to 2017 which was Rp. 12.4 trillion (Jayani, 2019).

The development of electronic money in Indonesia is supported by the increasing number of internet and smartphone users in Indonesia. Based on the results of an Indonesian Poll study in collaboration with the Indonesian Internet Service Providers Association (APJII), the number of internet users in Indonesia grew by $10.12 \%$ taken from field data during the period March to April 2019. Of the 264 million inhabitants of Indonesia, there are 171.17 million people or around $64.8 \%$ who have been connected to the internet. The biggest contribution come from Java Island with penetration rates reaching $55 \%$ of the total. In addition, from the majority of internet users in Indonesia, the users are people with an age range of 15 to 19 years (Pratomo, 2019).

Diagram 1.1 Internat Usage Levels of Millenial Generation and X Generation

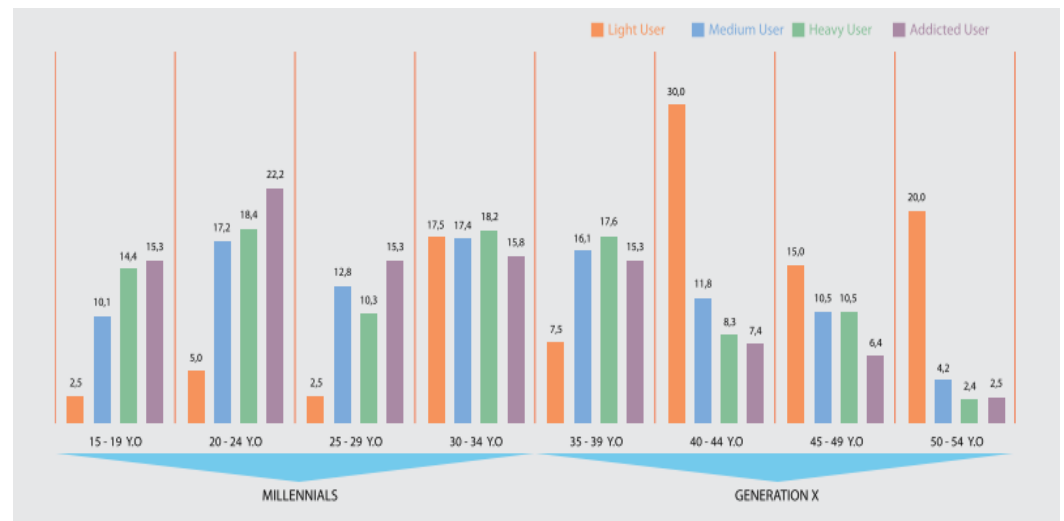

Source: Alvara Research Center, 2015

The result of the Alvara Research Center survey on internet use in Indonesia in 2015 shows that millennial generation internet consumption is much higher than the Gen-Xer, especially in younger millennials (15-24 years) (Purwandi, 2016, p. 15). The age of STEI SEBI students who are in that age range is something to pay attention to. Besides the fact that they are in the range of age, they are also students of STEI SEBI, a school that focuses on Islamic economics. They should at least understand about good financial management and the concept of fulfillment needs that are in accordance with Islamic teachings.

Despite the increase in electronic money and the largest contribution of internet users coming from Java with penetration rates reaching $55 \%$ of the 
66 | Nailah Fauziah, Nining Nurhasanah : The Effect of The Perception of Electronic Money on Consumptive Behavior of STEI SEBI Students

total, the largest population of poor people live in Java (12.72 million people) (Statistics, 2019, p. 3).

\section{LITERATURE REVIEW}

\section{Technology Acceptance Model}

The technology acceptance model (TAM) was developed by Davis et al. (1989). The Technology Acceptance Model is an adaptation of Theory Reasoned Action (TRA) developed by Fishbein and Ajzen (1975). TAM has the aim to provide a parsimonious explanation of the determinants of adoption of information technology user behavior towards the acceptance of the use of information technology itself (Davis et al., 1989). Parsimony is a term used to express thrifty in preparing assumptions or hypotheses that also means proof (Priambodo \& Prabawani, 2016, p. 3).

\section{Perception of Benefit}

Davis et al. (1989: 320) defines the perception of usefulness as a belief in expediency, which is the degree to which users believe that the use of technology / system will improve their performance at work. Perceived benefit is defined as the extent to which a person believes that the use of certain information systems will improve performance. Davis (1989) in Jogiyanto (2007: 152) indicators in forming perceptions of benefits are:

1) The ability to work faster

2) Effectiveness

3) the ability to make work easier

4) Usefullness

(Aliyah, 2016, p. 3)

\section{Perception of Ease of Use}

Ease of use is defined as the extent to which a person believes that using a technology will be free from effort (Jogiyanto. 2007: 114). Davis et al. (1989: 320) defines perceived ease of use as a belief in ease of use, namely the degree to which users believe that the technology / system can be used easily and free from problems. Intensity of use and interaction between users and the system can also show ease of use (Priambodo \& Prabawani, 2016, p. 4). Indicators in establishing ease of use are:

1) Clear and understandable

2) Not require a lot of mental effort in its use

3) Easy to use 
Jurnal Ekonomi dan Perbankan Syariah

Vol. 8. No.1, April 2020: 63-84 ISSN (printed): 2355-1755 | ISSN (online): 2579-6437

4) understand what the user wants (Aliyah, 2016, p. 4)

\section{Electronic Money}

\section{Definition of Electronic Money}

Electronic money is a payment instrument in electronic form where the value of the money is stored in certain electronic media. The user must first deposit the money to the publisher and save it in electronic media before using it for the purpose of the transaction. When used, the value of electronic money stored in electronic media will be reduced by the value of the transaction and afterwards it can be topped up (Indonesian, n.d.).

Based on Bank Indonesia Regulation No. $11 \backslash 12 \backslash$ PBI $\backslash 2009$ dated April 13, 2009 concerning Electronic Money, what is meant by Electronic Money is a means of payment that meets the following elements:

1) Issued on the basis of the value of money paid in advance by the holder to the issuer;

2) Value of money stored electronically in a medium such as a server or chip;

3) Used as a means of payment to traders who are not the issuers of the electronic money; and

4) The value of electronic money deposited by holders and managed by the issuer is not a deposit as referred to in the law governing banking (Indonesia, n.d.)

\section{Development of Electronic Money}

The development of electronic money has not only changed people's lifestyles socially but also influenced their economic behavior. This is reinforced by the results of a survey of the Indonesian Internet Service Providers Association (APJII) in 2017 reaching 143.26 million people $(54.68 \%)$ of Indonesia's total population of 262 million. This means that more than half the people in Indonesia use the internet, where the majority of internet users as much as 83.2 million people $(58.08 \%)$ are in Java, then Sumatra as much as $19.09 \%$, Kalimantan $7.97 \%$, Sulawesi $7.73 \%$, Bali-Nusa 5.63\%, and Maluku-Papua as much as $2.49 \%$ (Silalahi \& Pramedia Puspa, 2018, p. 13). In addition, the composition of internet users in Indonesia is dominated by productive age, namely $29.2 \%$ (ages $35-44$ ), 24.4\% (ages 25-34) and 18.4\% (ages 10-24) while the remaining elderly age ( Wulandari, 2017, p. 377).

Electronic money itself is divided into two types, the first is chipbased electronic money and the second is server-based electronic money. Since its development and took effect some time ago, as of March 26, 2020 there have been 45 electronic money providers of these two types circulating in Indonesia and have been registered at Bank Indonesia, namely: 
68 Nailah Fauziah, Nining Nurhasanah : The Effect of The Perception of Electronic Money on Consumptive Behavior of STEI SEBI Students

1) PT Artajasa Pembayaran Elektronis (MYNT E-Money)

2) PT Bank Central Asia Tbk (Sakuku dan Flazz)

3) PT Bank CIMB Niaga (Rekening Ponsel)

4) PT Bank DKI (Jakarta One/JakOne dan JakCard)

5) PT Bank Mandiri (Persero) Tbk (Mandiri e-Cash dan Mandiri eMoney)

6) PT Bank Mega Tbk (Mega Virtual dan Mega Cash)

7) PT Bank Negara Indonesia (Persero) Tbk (Unikqu dan TapCash)

8) PT Bank NationalInobu (Nobu e-Money)

9) PT Bank Permata (BBM Money)

10) PT Bank Rakyat Indonesia (T Bank dan Brizzi)

11) PT Finnet Indonesia (FinnChannel)

12) PT Indosat, Tbk (PayPro/Dompetku)

13) PT Nusa Satu Inti Artha (DokuPay)

14) PT Skye Sab Indonesia (Skye Mobile Money dan SkyeCard)

15) PT Telekomunikasi Indonesia, Tbk (Flexy Cash dan iVas Card)

16) PT Telekomunikasi Seluler (T-Cash dan Tap Izy)

17) PT XL Axiata, Tbk (XL Tunai)

18) PT Smartfren Telecom, Tbk (Uangku)

19) PT Dompet Anak Bangsa (Go-Pay)

20) PT Witami Tunai Mandiri (TrueMoney)

21) PT Espay Debit Indonesia Koe (Dana)

22) PT Bank QNB Indonesia, Tbk (Dooet)

23) PT BPD Sumsel Babel (BSB Cash)

24) PT Buana Media Teknologi (Gudang Voucher)

25) PT Bimasakti Multi Sinergi (Speed Cash)

26) PT Visionet Internasional (OVO Cash)

27) PT Inti Dunia Sukses (iSaku)

28) PT Veritra Sentosa Internasional (Paytren)

29) PT Solusi Pasti Indonesia (KasPro)

30) PT Bluepay Digital Internasional (Bluepay)

31) PT Ezeelink Indonesia (Ezeelink)

32) PT E2Pay Global Utama (M-Bayar)

33) PT Cakra Ultima Sejahtera (DUWIT)

34) PT Airpay Internasional Indonesia (SOPEEPAY)

35) PT Bank Sinarmas (Simas e-Money)

36) PT Transaksi Artha Gemilang (OttoCash)

37) PT Fintek Karya Nusantara (LinkAja)

38) PT Max Interactives Technologies

39) PT Sarana Pactindo

40) PT Datacel Infomedia

41) PT Kereta Commuter Indonesia

42) PT Mass Rapid Transit Jakarta

43) PT Netzme Kreasi Indonesia

44) PT Bank BNI Syariah 


\section{5) PT MNC Teknologi Nusantara}

(Bank Indonesia, 2020).

The growth of electronic money was also driven by the launching of the Grand Design effort to increase the use of non-cash payments, or what is often referred to as Toward a Less Cash Society by Bank Indonesia as the holder of the Indonesian payment system regulatory authority. Changes in the payment system to the Less Cash Society are inevitable. Less Cash Society is defined as a culture or trend that develops in the community in conducting payment transactions through non-cash payment media.

\section{Legal Basis for Providing Electronic Money}

The administration of Electronic Money is regulated in:

1) Bank Indonesia Regulation Number 11/12 / PBI / 2009 dated April 13, 2009 concerning Electronic Money.

The regulatory material contained in this Bank Indonesia Regulation includes but is not limited to:

- Procedures for licensing and licensing transfers;

- Procedures for implementation;

- Oversight;

- Enhanced technological security; and Penalty. (Bank Indonesia, 2009).

2) Bank Indonesia Circular No.11 / 11 / DASP dated April 13, 2009 concerning Electronic Money.

This circular is an implementing regulation of Bank Indonesia Regulation Number 11/12 / PBI / 2009 April 13, 2009 concerning Electronic Money. (Bank Indonesia, 2009).

\section{Electronic Money Law in Islamic Perspective}

Digital money is a neutral feature that depends on the substance and goods being traded. If the user can fulfill their primary halal interests easily with this instriment, then the importance of this application is the same as buying goods without having to provide cash in his/her wallet and without having to come to the merchant and other hassles. This is based on the principle of jurisprudence "Facilities that have the same law with the goal". The use of digital money has been regulated in DSN MUI Fatwa No. 116 / DSN-MUI / IX / 2017 concerning Islamic Electronic Money and AAOIFI Standards No. 38 of at-Ta'amulat al-Elektroniah (Sahroni, 2019). 
70 |Nailah Fauziah, Nining Nurhasanah : The Effect of The Perception of Electronic Money on Consumptive Behavior of STEI SEBI Students

Sharia law itself is permitted if the funds placed by the user in a digital wallet are: (1) used by the issuer with discounts given at the initiative of the issuer (without conditions). (2) not used by digital money issuers. Meanwhile, if used by the publisher, with the required discount, then it becomes usury. The purpose of the first point is that users do top-ups based on other factors (such as ease of transaction and the issuer does not always give a discount for every use of digital money) not because there is a discount and the issuer certainly gives a discount for each use of digital money as promised. (Sahroni, 2019).

\section{Consumptive Behavior}

\section{Definition of Consumptive Behavior}

Consumptive behavior is the act of buying goods with emotional consideration and buying behavior that is more dominated by desires outside of needs and only to fulfill desires only (Gumulya \& Widiastuti, 2013, p. 52). Consumptive behavior is also a directional consumption behavior, sometimes it just follows the prestige and only follows the trend (Philip, 2019, p. 2).

\section{Indicators of Consumptive Behavior}

Indicators of consumptive behavior according to Sumartono (2002) are as follows:

a. Buy the product because of the lure of gifts

Individuals buy an item because of the prize offered if they buy the item, without thinking about the size of the item's functioning.

b. Buy a product because the packaging is attractive

Consumers are very easily persuaded to buy products that are neatly wrapped and decorated with attractive colors. This means that the motivation to buy the product is only because the product is neatly wrapped and attractive. c. Buy products to maintain self-appearance and prestige

Consumers have a high desire to buy, because in general a person has characteristics in dressing, dressing up, hairstyle, and so on with the aim that the person always looks that can attract the attention of others. The person spends more money to support his appearance.

d. Buy products based on price (not based on benefits or uses)

Consumers tend to behave as indicated by the existence of luxurious life so they tend to use everything that is considered the most luxurious. e. Buying a product is just keeping the status symbol

Usually people have a high purchasing ability both in dressing, dressing, hair style, and so on so that it can support the exclusive nature of 
expensive items and give the impression of coming from a higher social class. Buying a product can give a status symbol to look cooler in the eyes of others. f. Use the product $n$. Use the product because of the conformity of the advertising model

Someone tends to imitate the behavior of the idol in the form of using everything that can be used by his idol. The person also tends to use and try the products offered if he idolizes the public figure of the product.

$\mathrm{g}$. The emergence of an consideration that buying products at high prices will lead to high confidence

Sometimes there are people who are very encouraged to try a product because they believe what is said by the advertisement that can foster confidence. Cross and Cross (in Hurlock, 1999) also add that by buying products that they think can enhance their physical appearance, they will become more confident.

h. Try more than two similar products (different brands)

Some people will tend to use the same type of product with other brands than the previous product he uses, even though the product has not been used.

In the case when there is a relationship between two variables, for example between variable $\mathrm{Y}$ and variable $\mathrm{X}$, then if variable $\mathrm{Y}$ is caused by variable $\mathrm{X}$, then variable $\mathrm{Y}$ is called the dependent variable and variable $\mathrm{X}$ is the independent variable. Variables that depend on other variables are called dependent variables (Nazir, 2011, p. 124). Based on the theoretical basis and previous research on the dependent variable (consumptive behavior of STEI SEBI students) with the independent variable (perception of the use of electronic money) above, the theoretical framework can be developed as shown in the following figure:

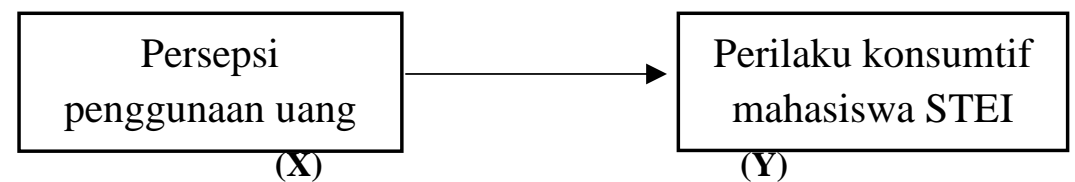

\section{RESEARCH METHODOLOGY}

\section{Types and Nature of Research}

This type of research is field research, which is conducted on all SEEI STEI students who have conducted transactions using electronic money. This research is descriptive-quantitative, descriptive, that is describing and explaining the influence of independent variables, namely the perception of the use of electronic money on the consumer behavior of STEI SEBI students. Quantitative because the research data in the form of numbers and analyzed 
72 Nailah Fauziah, Nining Nurhasanah : The Effect of The Perception of Electronic Money on Consumptive Behavior of STEI SEBI Students

using statistics. The analysis in this study uses statistics with the help of SPSS statistical computer applications.

\section{Data Type}

This research uses primary and secondary data types. Primary data is data collected for research from the actual location of the event (Sekaran, 2011). Data was collected with a questionnaire given to respondents and deepened through interviews. Data from the questionnaire were scored in the form of numbers and then tested and analyzed.

In addition to using primary data, this study also uses secondary data. Secondary data (Sugiyono, 2012: 141) defines that secondary sources are sources of data obtained by reading, studying and understanding through other media sourced from literature, books and company documents.

\section{Data collection technique}

Data collection techniques are ways and tools used by researchers to collect data. Secondary data collection techniques in this study were obtained from books, journals, websites, related news and several Bank Indonesia documents. And primary data collection techniques in this study were obtained from respondents' answers collected through questionnaires and deepened through interviews.

According to Arikunto (2013: 194), a questionnaire is a number of written questions that are used to obtain information from respondents in the sense of reports about his personality, or things he knows. The questionnaire in this study was aimed at STEI SEBI students and distributed online through social media groups aimed at knowing the perceptions of STEI SEBI students in using electronic money.

According to Stewart and Cash (2012), interviewing is a process of communication between two parties that at least one of them has a serious goal that has been set and involves a question and answer process about something. Interviews were conducted with several respondents (students of STEI STEI) to find out more deeply the reasons of respondents when answering questionnaires.

\section{Population}

Population is a collection of elements that show certain characteristics that can be used to make conclusions (Sanusi, 2011: 87). So, the collection of 
elements shows the amount, while certain characteristics indicate the characteristics of the collection. The population in this study were all SEEI STEI students.

Table 3.3 Active Students of STEI SEBI 2019/2020

\begin{tabular}{|l|l|l|l|l|l|l|}
\hline \multirow{2}{*}{ No. } & Jurusan & \multicolumn{3}{|l|}{ Angkatan } & Jumlah \\
\cline { 3 - 7 } & & $\mathbf{2 0 1 6}$ & $\mathbf{2 0 1 7}$ & $\mathbf{2 0 1 8}$ & $\mathbf{2 0 1 9}$ & \\
\hline 1. & $\begin{array}{l}\text { Manajemen Perbankan } \\
\text { Syariah }\end{array}$ & 71 & 99 & 122 & 71 & 363 \\
\hline 2. & Akuntansi Syariah & 87 & 62 & 100 & 68 & 317 \\
\hline 3. & Manajemen Bisnis Syariah & 57 & 64 & 101 & 106 & 328 \\
\hline 4. & Hukum Ekonomi Syariah & & & & 38 & 38 \\
\hline & Total & $\mathbf{2 1 5}$ & $\mathbf{2 2 5}$ & $\mathbf{3 2 3}$ & $\mathbf{2 8 3}$ & $\mathbf{1 . 0 4 6}$ \\
\hline
\end{tabular}

Source: Academic Data of STEI SEBI

\section{Sample}

The sample is part of the population, the sample consists of a number of members selected from the population. The sample criteria of this study are for STEI SEBI students who have made transactions using electronic money. The number of samples in this study was determined using the Slovin formula, which is as follows:

$$
\begin{gathered}
n=\frac{N}{1+N \epsilon^{2}} \\
n=\frac{N}{1+N \epsilon^{2}} \\
n=\frac{1046}{1+1046(10 \%)^{2}} \\
n=\frac{1046}{1+1046(0,01)} \\
n=\frac{1046}{11,46} \\
n=91
\end{gathered}
$$

Information :

$\mathrm{n}=$ number of samples

$\mathrm{N}=$ population size

$\mathrm{e}=$ error limit $(10 \%)$

With the STEI SEBI student population totaling 1046 people and the error limit set at $10 \%$ (significance level or error tolerance), the number of 
74 | Nailah Fauziah, Nining Nurhasanah : The Effect of The Perception of Electronic Money on Consumptive Behavior of STEI SEBI Students

samples to be taken is 91 STEI SEBI student respondents by dividing each study as follows:

Table 4.2 Distribution of Samples

\begin{tabular}{|l|l|l|l|}
\hline No. & Jurusan & Jumlah & Sampel \\
\hline 1. & $\begin{array}{l}\text { Manajemen Perbankan } \\
\text { Syariah }\end{array}$ & 363 & 32 \\
\hline 2. & Akuntansi Syariah & 317 & 28 \\
\hline 3. & Manajemen Bisnis Syariah & 328 & 28 \\
\hline 4. & Hukum Ekonomi Syariah & 38 & 3 \\
\hline \multicolumn{2}{|l|}{ Total } & $\mathbf{1 . 0 4 6}$ & $\mathbf{9 1}$ \\
\hline
\end{tabular}

Source: Data processed

\section{Sampling technique}

The sampling technique used in this study is non-probability sampling, namely by purposive sampling. Purposive sampling is a technique with certain considerations (Sugiyono, Statistics for Research, 2012). What is meant by certain considerations in purposive sampling is a sampling technique using sample selection criteria. The sample selection criteria in this study are those who have conducted transactions using electronic money.

\section{Research Instruments}

The instrument used in this study consisted of three instruments, namely the Likert Scale, the Technology Acceptance Model and the Consumptive Behavior Indicator.

Likert scale itself can be defined as a psychometric scale which is commonly used in questionnaires / questionnaires and is the scale most widely used in research in the form of surveys. The name of the scale is taken from the name of Rensis Likert, who published a report explaining its use. When responding to a question on a Likert scale, respondents determine their level of agreement with a statement by choosing one of the available choices. Usually in a Likert scale five options are provided in this format: 1) Strongly Disagree; 2) Disagree; 3) Neutral; 4) Agree; and 5) Strongly Agree.

Electronic money measurement instruments (X) use the Technology Acceptance Model (TAM) 
Jurnal Ekonomi dan Perbankan Syariah

Vol. 8. No.1, April 2020: 63-84 ISSN (printed): 2355-1755 | ISSN (online): 2579-6437

Table 3.1 Technology Acceptance Model (TAM)

\begin{tabular}{|c|c|c|}
\hline Konsep & Indikator & Referensi \\
\hline $\begin{array}{l}\text { Persepsi } \\
\text { Kemanfaatan }\end{array}$ & 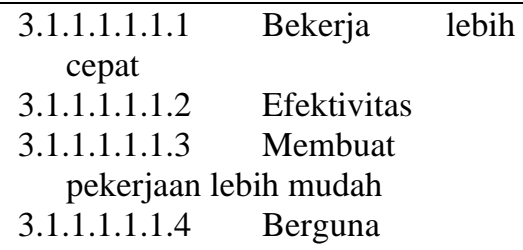 & 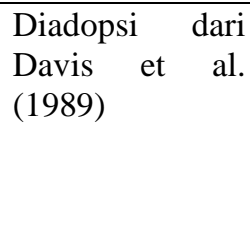 \\
\hline $\begin{array}{l}\text { Persepsi } \\
\text { Kemudahan } \\
\text { Penggunaan }\end{array}$ & $\begin{array}{l}\text { 1. Jelas dan dapat dimengerti } \\
\text { 2. Tidak membutuhkan usaha } \\
\text { mental yang banyak dalam } \\
\text { penggunaannya } \\
\text { 3. Mudah digunakan } \\
\text { 4. Sistem mudah memahami apa } \\
\text { yang diinginkan pengguna }\end{array}$ & 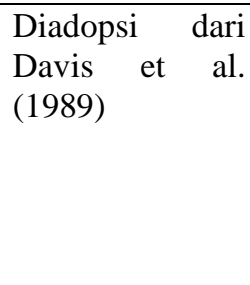 \\
\hline
\end{tabular}

Then to measure the consumptive behavior (Y), this study uses indicators of consumptive behavior according to Sumartono (2002)

Table 3.2 Indicators for Consumer Behavior Sumartono (2002)

\begin{tabular}{|l|l|l|}
\hline Konsep & Indikator & Referensi \\
\hline Perilaku & 1. Membeli produk karena & Diadopsi dari \\
& $\begin{array}{l}\text { iming-iming hadiah. } \\
\text { 2. Membeli produk karena } \\
\text { kemasannya menarik. }\end{array}$ & \\
3. Membeli produk demi \\
menjaga penampilan dan \\
gengsi. 2002) \\
4. Membeli produk hanya \\
sekedar menjaga simbol \\
status.
\end{tabular}


76 | Nailah Fauziah, Nining Nurhasanah : The Effect of The Perception of Electronic Money on Consumptive Behavior of STEI SEBI Students

\section{Data analysis technique}

The analysis technique used to test hypotheses is a simple linear regression analysis technique. Data analysis begins by testing the validity and reliability. Then a simple regression was conducted which looked at the perception of the use of electronic money on the consumer behavior of STEI SEBI students.

\section{Test Validity}

According to Arikunto (2006: 211) validity is a measure that shows the level of validity of an instrument. Valid means that the instrument can be used to measure what should be measured. To test the validity is done by correlating the score of each item with the total score. An instrument is said to be valid if it is able to measure what is desired and can reveal data from the variables studied appropriately. The validity test used in this study is the Pearson Product Moment correlation as follows:

$$
r_{x y}=\frac{N \Sigma x y_{-(\Sigma x)}\left(\sum y\right)}{\sqrt{\left(N \Sigma x^{2}-\left(\sum x\right)^{2}\left(N \Sigma y^{2}-(\Sigma y)^{2}\right)\right.}}
$$

Information :

$\mathrm{r}=$ Correlation coefficient between items ( $\mathrm{x}$ ) with a total score (y)

$\mathrm{x}=$ Score of each item

$\mathrm{y}=$ total score

$\mathrm{n}=$ Number of respondents

The validity of each question is determined by the amount of $r$ that can be known from the results of data processing through the SPSS program that is by using correlation, where the level of significance $(\alpha)=5 \%$. If the calculated value is greater than rtable, then the variable is valid. If the calculated value is smaller than rtable, then the variable is invalid.

\section{Reliability Test}

An instrument has a high reliability if the instrument is sufficiently trusted and reliable to be used as a data collection tool because the instrument is already good (Arikunto, 2006: 221). Reliability means that it can be trusted, so it can be relied upon. The reliability test measurement of this study uses the Cronbach alpha technique with SPSS software. Chronbach alpha method is used to calculate the reliability of a test that measures attitude or behavior 
(Siregar, 2015: 89). The research instrument is said to be reliable if the reliability coefficient $>0.60$.

\section{Descriptive Analysis}

Descriptive analysis includes the transformation of raw data into a form that will provide information to explain a set of factors in a situation (Sekaran, 2006: 285). Descriptive statistical analysis includes the mean (mean), standard deviation, maximum value and minimum value. The division of categories in this study uses the ideal value to see the tendency of electronic money variable data and consumptive behavior.

\section{Classical Assumption Test}

\section{a. Normality test}

Normality testing is a test of normality performed for parametric statistical analysis. Normality test is used to determine whether the data is normally distributed or not. This test uses the Kolmogorof Smirnov method. The criteria for normality are as follows:

1) If the value of sig (significance) > alpha, then normal / pass

2) If the sig (significance) value <alpha, then it is not normal

\section{b. Heteroscedasticity Test}

Heteroscedasticity test can be done with Glejser Test, by regressing the absolute residual value. Decisions are taken if there is no significant relationship between all independent variables on absolute residual values, so it can be concluded that the assumption of non-heteroscedasticity is fulfilled.

\section{Simple Regression Test}

Simple regression analysis is an analysis used to measure one independent variable (the use of electronic money) against one dependent variable (consumptive behavior). A simple linear regression equation can be written:

$\mathbf{Y}=\mathbf{a}+\mathbf{b X}$

Information:

$\mathrm{Y}=$ Dependent variable (financial behavior)

$\mathrm{X}=$ free variable (using fintech)

$\mathrm{a}=$ constant

$\mathrm{b}=$ coefficient 
78 |Nailah Fauziah, Nining Nurhasanah : The Effect of The Perception of Electronic Money on Consumptive Behavior of STEI SEBI Students

\section{a. Partial Regression Test (t Test)}

This test is used to determine whether the independent variable (X) significantly influences the dependent variable (Y). Significant means the influence that occurs can apply to the population (can be generalized).

$\mathrm{T}$ arithmetic formula in regression analysis is as follows:

$$
\text { thitung }=\frac{b}{s b} \quad \text { atau } \quad \text { thitung }=\frac{r \sqrt{n-2}}{\sqrt{1-r^{2}}}
$$

Information:

$\mathrm{b}=$ Regression Coefficient

$\mathrm{Sb}=$ Standard Error

$r=$ Simple Correlation Coefficient

$\mathrm{n}=$ Number of data or cases

\section{b. R Square Analysis}

$\mathrm{R}$ Square can be seen from the results of the regression analysis of the Summary Model table. R Square is adjusted R2 (Priyatno, 2009: 134). The value obtained shows the contribution of the influence of independent variables on the dependent variable. $\mathrm{R}$ Square is more recommended in evaluating the regression analysis because with the coefficient of determination (R2) can lead to habits of the number of independent variables entered into the model. Every addition of one independent variable, then R2 must increase regardless of whether the variable significantly influences the dependent variable or not (Ghozali, 2005: 83).

\section{ANALYSIS AND DISCUSSION}

\section{Characteristics of Respondents}

Characteristics of respondents in this study include age, gender, study program, year of force, having other jobs besides students, type of work and income / allowance per month. Detailed characteristics of the respondents have been summarized in the diagram below: 
Jurnal Ekonomi dan Perbankan Syariah

Diagram 4.1 Based on Age

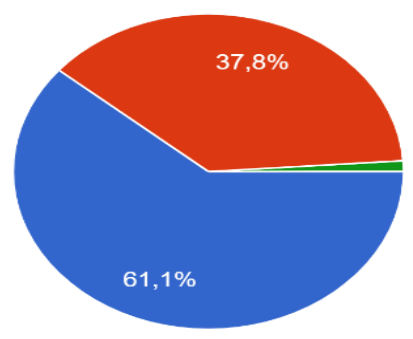

The diagram above shows that the age of the majority of respondents ranged from 18-21 years with 56 people with a percentage of $61.1 \%$, aged 22 24 years with 34 people with a percentage of $37.8 \%$, aged over 28 years with 1 person with a percentage of $1,1 \%$, and the age of the respondents who were at least ranged from 25-27 namely as many as 0 people with a percentage of $0 \%$.

\section{Diagram 4.2 Based on Gender}

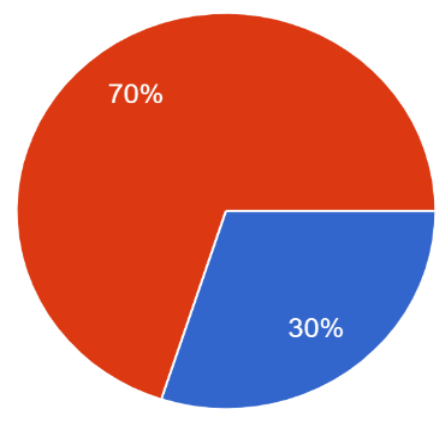

Laki-laki

Perempuan

Source: Data processed

The majority of respondents were female as many as 64 people with a percentage of $70 \%$ and male respondents numbered 27 people with a 
80 |Nailah Fauziah, Nining Nurhasanah : The Effect of The Perception of Electronic Money on Consumptive Behavior of STEI SEBI Students

percentage of $30 \%$. This is because women use public transportation more often than men who on average have a private vehicle and are able to drive it.

\section{Diagram 4.3 Based on Study Program}

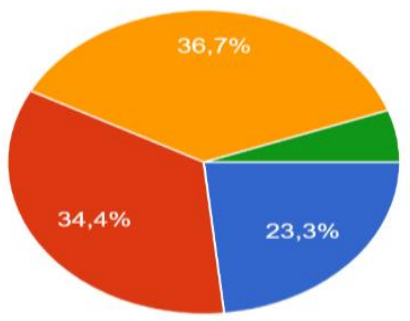

Akuntansi Syariah

Manajemen Perbankan Syariah

Manajemen Bisnis Syariah

Hukum Ekonomi Syariah

Source: Data processed

For the study program, the majority of respondents came from the Sharia Business Management study program as many as 34 people with a percentage of $36.7 \%$, then Sharia Banking Management as many as 31 people with a percentage of $34.4 \%$, then Sharia Accounting as many as 21 people with a percentage of $23.3 \%$ and the least came from Islamic Economics Law study programs, namely as many as 5 people with a percentage of $5.6 \%$. The reason why Sharia Business Management owns and uses electronic money more is because on average they need electronic money for their business activities.

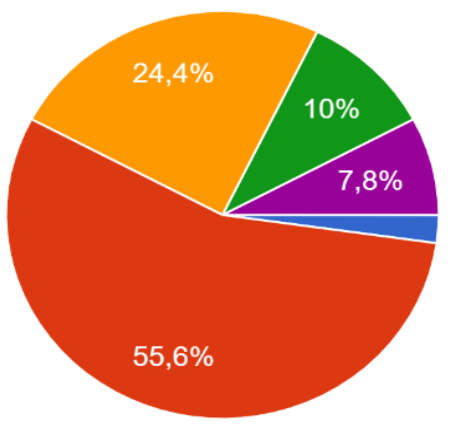


For the year of generation, the majority of respondents were in the class of 2016 with 51 people with $55.6 \%$ percentage, then in 2017 there were 22 people with a percentage of $24.4 \%$, then in 2018 there were 9 people with a percentage of $10 \%$, then in 2019 there were 7 people with a percentage $7.8 \%$ and the least is the class of 2015 which is 2 people with a percentage of $2.2 \%$.

Diagram 4.5 Based on Employment Status

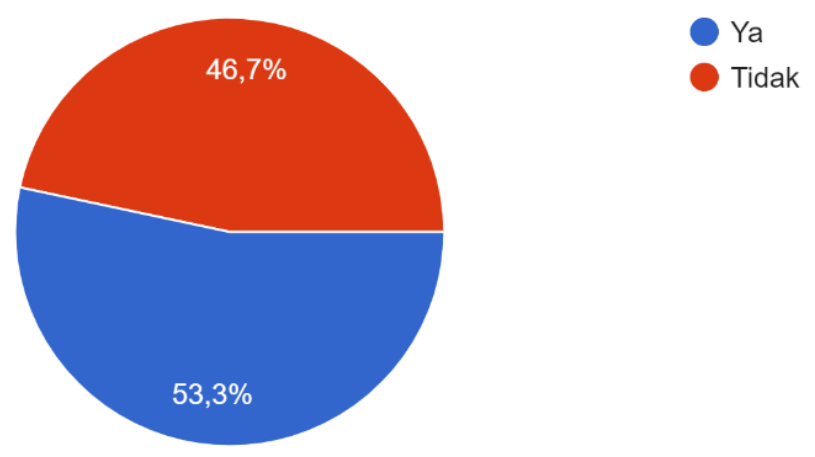

Source: Data processed

Then for jobs other than students, 49 people with a percentage of $53.3 \%$ have other jobs besides students, while 42 others with a percentage of $46.7 \%$ do not have jobs other than students.

\section{Diagram 4.6 Based on Job Type}

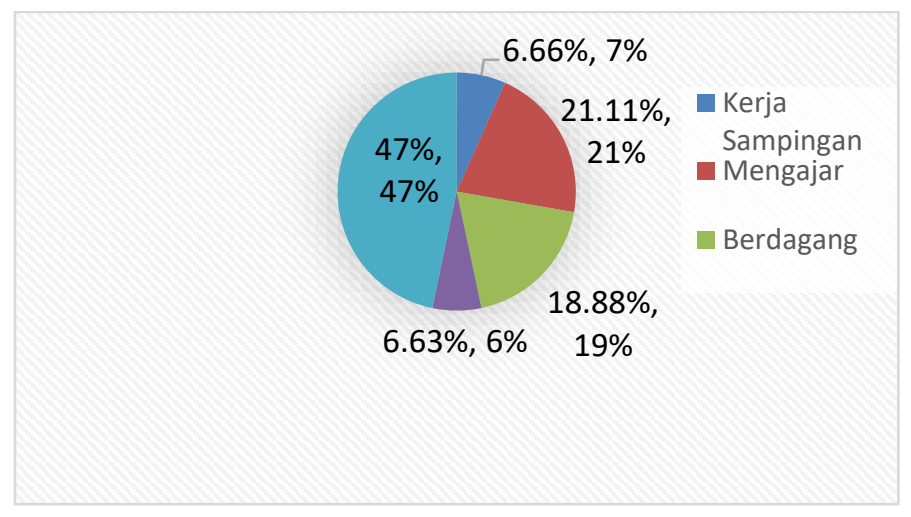

Source: Data processed 
82 |Nailah Fauziah, Nining Nurhasanah : The Effect of The Perception of Electronic Money on Consumptive Behavior of STEI SEBI Students

For employment positions, the majority of respondents do not work, as many as 42 people with a percentage of $46.7 \%$ or rounded to $47 \%$, then as a teacher / teacher as many as 20 people with a percentage of $21 \%$, then trade as many as 17 people with a percentage of $19 \%$, and positions the least occupations are part time / part time jobs and other types of work (other than those listed as options) of 6 people.

\section{Diagram 4.7 Based on Income / Allowance Per Month}

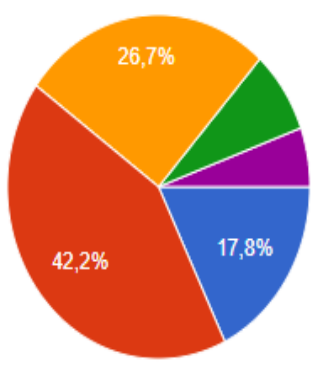

$<$ Rp. 500.00

Rp. 500.000 - Rp. 999.999

Rp. 1.000 .000 - Rp. 1.999 .999

Rp. 1.500 .000 - Rp. 1.999 .999

_ $>$ Rp. 2.000 .000

\section{Source: Data processed}

And the last income / allowance per month, the majority of respondents get income / allowance per month ranging from Rp. 500,000 - Rp. 999,999 as many as 39 people with a percentage of $42.2 \%$ and the least are respondents who get income / pocket money per month _> Rp. 2,000,000 as many as 5 people with a percentage of $5.6 \%$.

\section{Interview result}

After conducting an interview to find out the reason of the respondent's answer, it can be concluded that the reason for responding to using electronic money in addition to its many benefits and is easy to use is because of the many attractive promos and cashback offered quite tempting. But behind the convenience and benefits offered, there are respondents' concerns in terms of security. Because in principle electronic money is the same as cash, which is when electronic money is lost then it can be used by other parties and cannot be claimed to the issuer. Then when the system dies, automatic electronic money cannot be used. In addition to concerns about the security system, some parties such as the elderly lack understanding of the use of electronic money. So that more intensive socialization is needed so that each group is able to transact using electronic money. 
Based on interviews with several respondents obtained information that in addition to increasing consumer behavior electronic money is also very useful, for people who travel frequently it is very easy to pay for using some transportation, and for people whose average activity is at home, electronic money also makes it easy for them to shop so you don't have to bother leaving the house. Besides being useful the electronic money system is also easy to use, one of which is because it can be connected with a device so that it is easily monitored and also used.

\section{Partial Regression Test Results (t test)}

Based on the results of the partial regression test ( $t$ test) showed that the variable perception of the use of electronic money in this study had a positive and significant influence on the consumer behavior of STEI SEBI students. These results support the hypothesis which shows that the perception of the use of electronic money has a positive and significant effect on the consumer behavior of STEI SEBI students. That is, with the high use of electronic money, the consumption behavior of STEI SEBI students will also increase. Then it can be concluded Ha ACCEPTED.

\section{CONCLUSION}

This study examines the effect of the perception of the use of electronic money on the consumer behavior of STEI SEBI students. Where the perception of the use of electronic money becomes the dependent variable and consumptive behavior as the independent variable. Based on the results of research and discussion, the following conclusions can be drawn: 1) Electronic money has a positive and significant impact on the level of millennial generation consumption. 2) When the use of electronic money is high, the consumption behavior of STEI SEBI students will also increase. 3) The link between electronic money and consumptive behavior can be categorized quite well. 
84 | Nailah Fauziah, Nining Nurhasanah : The Effect of The Perception of Electronic Money on Consumptive Behavior of STEI SEBI Students

\section{BIBLIOGRAPHY}

Bank Indonesia. (2009, April 13). Bank Indonesia. Dipetik Maret 12, 2020, dari Bank Indonesia: http://www.bi.go.id/peraturan/sistempembayaran/pbi_1111209

Bank Indonesia. (2009, 12 11). Bank Indonesia. Retrieved Maret 12, 2020, from Bank Indonesia: https://www.bi.go.id/id/peraturan/sistempembayaran/se_111109

Bank Indonesia. (2020, Maret 26). Bank Indonesia. Retrieved Maret 27, 2020, from Bank Indonesia: http://www.bi.go.id

Kahf, M. (1997). as-Siyasah al-Iqtishadiyah fi ithari al-Islami. Islamic Research and Training Institute, 207.

Kasali, R. (2017). Disruption. Jakarta: PT Gramedia Pustaka Utama.

Mudawam, S. (2000). Ekonomi Islam dalam Prospek Pembangunan Umat Islam . Jurnal Ekonomi Sosial Politik, 109-123.

Sahroni, O. (2019, Oktober 23). Diskon dan Cashback Uang Digital. Depok, Jawa Barat, Indonesia.

Sahroni, O. (2019, Oktober 4). Fikih Uang Digital. Depok, Jawa Barat, Indonesia.

Suprayitno, E. (2005). Ekonomi Islam Pendekatan Ekonomi Makro Islam dan Konvesional. Yogyakarta: Graha Ilmu. 